\title{
Usefulness of Noninvasive Methods for the Study of Bronchial Inflammation in the Control of Patients with Asthma
}

\author{
Xavier Muñoz ${ }^{a, b, d}$ Victor Bustamante ${ }^{e}$ José-Luis Lopez-Campos ${ }^{d, f}$ \\ María-Jesús Cruz $^{a, d}$ Esther Barreiroc, d \\ a Pulmonology Service, Medicine Department, Hospital Universitari Vall d'Hebron and 'bepartment of Cell Biology, \\ Physiology and Immunology, Universitat Autònoma de Barcelona, and CPulmonology Department-Muscle \\ Research and Respiratory System Unit, Institut Hospital del Mar d'Investigacions Mèdiques (IMIM), Hospital del Mar, \\ Department of Experimental and Health Sciences, Universitat Pompeu Fabra, Parc de Recerca Biomèdica de \\ Barcelona (PRBB), Barcelona, dCentro de Investigación en Red de Enfermedades Respiratorias (CIBERES), Instituto \\ de Salud Carlos III, Madrid, e Pneumology Department, Hospital Universitario Basurto, Osakidetza/University of \\ the Basque Country, Basque Country, ${ }^{\mathrm{f} U n i d a d}$ Médico-Quirúrgica de Enfermedades Respiratorias, Instituto de \\ Biomedicina de Sevilla, Hospital Universitario Virgen del Rocío/Universidad de Sevilla, Seville, Spain
}

\section{Key Words}

Induced sputum - Exhaled breath condensate - Volatile organic compounds $\cdot$ Exhaled nitric oxide $\cdot$ Eosinophils

\begin{abstract}
Bronchial asthma is one of the most prevalent respiratory conditions. Although it is defined as an inflammatory disease, the current guidelines for both diagnosis and follow-up of patients are based only on clinical and lung function parameters. Current research is focused on finding markers that can accurately predict future risk, and on assessing the ability of these markers to guide medical treatment and thus improve prognosis. The use of noninvasive methods to study airway inflammation is gaining increasing support. The study of eosinophils in induced sputum has proved useful for the diagnosis of asthma; however, its clinical implementation is complex. Some studies have shown that the measurement of exhaled nitric oxide (FeNO) may also be useful to establish disease phenotypes and improve control. Others have found that the measurement of $\mathrm{pH}$ and certain markers of oxidative
\end{abstract}

stress, cytokines and prostanoids in exhaled breath condensate $(E B C)$ may also be useful as well as the measurement of the temperature of exhaled breath and the analysis of volatile organic compounds (VOCs). In conclusion, since asthma is an inflammatory disease, it seems appropriate to try to control it through the study of airway inflammation using noninvasive methods. In this regard, the analysis of induced sputum cells has proved very useful, although the clinical implementation of this technique seems difficult. Other techniques such as temperature measurement, the analysis of FeNO, the analysis of the VOCs in exhaled breath, or the study of certain biomarkers in EBC require further study in order to determine their clinical applicability.

(c) 2015 S. Karger AG, Basel

\section{Introduction}

Bronchial asthma is one of the most common respiratory diseases and its incidence has increased in recent decades $[1,2]$. It is characterized by airway inflammation,

\section{KARGER 125}

() 2015 S. Karger AG, Base

$1018-2438 / 15 / 1661-0001 \$ 39.50 / 0$ 
bronchial hyperreactivity and chronic obstructive pulmonary disease (COPD) of varying degrees of reversibility [3]. Fortunately, most cases are mild and are not difficult for family physicians to diagnose and treat [4]. However, there are many situations in which the diagnosis is more demanding or is of greater significance, as in the case of work-related asthma; in other cases the management of the disease is complicated by being refractory to treatment due to associated factors, clinical or inflammatory disease phenotypes or comorbidities. Asthma patients present with particularly high morbidity and mortality, and the disease represents a major financial burden for health systems $[5,6]$.

Since asthma is an incurable disease, the goal of all current treatment strategies is limited to its control, to the extent that its manifestations can be reduced or removed [3]. The assessment of asthma control should include two aspects: current clinical control and future risk, understood as the ability to reduce or minimize the number of exacerbations, decreased lung function and the occurrence of adverse effects due to treatment [7]. Current guidelines base their treatment recommendations on achieving control, basically by adjusting the treatment according to the symptoms presented and trusting that symptom control will prevent the occurrence of exacerbations and the possible impairment of lung function [3, 8]. However, this may not always be the case. In fact, recent studies have identified discordant phenotypes of asthma in which the symptoms are not necessarily related to the degree of airway inflammation $[9,10]$. Morever, marked inflammation of airways in asthma patients may persist even if the disease appears to be controlled [11].

Since asthma is an inflammatory disease, several authors have measured it by enumerating inflammatory cells by means of endobronchial biopsies and bronchoalveolar lavage $[12,13]$. This strategy has proved useful, as it identifies different asthma phenotypes $[14,15]$ and allows the use of different treatments to address the physiopathological mechanisms that cause a particular type of inflammation [16-18]. However, these methods cannot be applied in the routine monitoring of asthmatic patients. This situation, together with the new trend towards defining not only inflammatory but also molecular phenotypes [19], has increased the interest in defining the type of inflammation and in seeking different types of biomarkers by noninvasive methods. This review focuses on the different noninvasive or minimally invasive methods to measure airway inflammation that can help achieve the goal of a better-suited, more personalized and effective treatment for asthma patients. Using a similar ap- proach, several authors have proposed adjusting treatment in accordance with the degree of bronchial hyperresponsiveness and observed improved control [20,21]; this point will not be discussed here.

\section{Induced Sputum}

Cellular analysis of sputum is a minimally invasive method that may be useful for diagnosis, differential diagnosis and adjustment of treatment in patients with bronchial asthma [22, 23]. Induced sputum analysis comprises two steps: sputum induction and sputum processing, both of which are well validated [24]. Sputum production is induced by the inhalation of hypertonic saline solution using an ultrasonic nebulizer. In general, patients are pretreated with inhaled salbutamol $10 \mathrm{~min}$ before nebulization with increasing concentrations of hypertonic saline (3, 4 and $5 \%$ ) for $5 \mathrm{~min}$. Prior to each nebulization, spirometry is performed because if a decrease in $\mathrm{FEV}_{1}$ of $>20 \%$ of the baseline is observed, the procedure should be discontinued [25]. After induction, the sputum samples must be processed within $2 \mathrm{~h}$ to ensure the optimal retrieval of information on the inflammatory cells and inflammatory mediators present in the airways. Complete homogenization can be achieved by the addition of an equal volume of dithiothreitol solution to the whole sample or of 4 times the volume of a selected plug. This is important in order to release cells from the mucus and to allow their identification. To separate cells from the sputum fluid phase, the sample must be centrifuged and the cell concentration adjusted to $1.0 \times 10^{6}$ cells $/ \mathrm{ml}$, in order to perform a cytospin preparation for cytocentrifugation. After cytospin staining, the differential cellular count is determined by counting a minimum of 400 nonsquamous cells, and is reported as relative numbers of eosinophils, neutrophils, lymphocytes, macrophages and epithelial cells [26] (fig. 1). Due to its complexity, however, this technique cannot be widely recommended.

At least 3 pathological phenotypes of asthma have been proposed, based on the predominant cell type involved, i.e. eosinophilic, neutrophilic and paucigranulocytic [14]. When eosinophilic inflammation is not predominant or when concomitant presence of both eosinophils and neutrophils (mixed cellularity) is observed, the disease appears to be more severe [27, 28]. Eosinophilic inflammation is likely to have a Th2 immune component, a reflection of adaptive immunity $[9,29]$, and treatment with inhaled or systemic corticosteroids is usually helpful even for smokers or former smokers [30]. The mecha- 
nisms for airway neutrophilia are less clear. Th1 factors may play a role [31] and Th17 immunity has been implicated in some cases of severe asthma [32]. Finally, the mechanisms in patients with little or no inflammation may involve the activation of resident cellular elements including smooth-muscle cells, fibroblasts and neurons [33]. Treatment with corticosteroids appears to be less useful in the last 2 phenotypes [34]. In this context, differentiating the type of inflammation in asthma patients may be useful to establish the best treatment possible.

In the last decade, several authors have proposed the use of the eosinophil count in induced sputum to optimize the treatment of asthma patients and reduce the risk of exacerbations. Green et al. [35] recruited 74 patients with moderate to severe asthma and randomly allocated them to management either by British Thoracic Society asthma guidelines or by normalization of the induced sputum eosinophil count and reduction of symptoms. After 1 year of follow-up, the sputum eosinophil count and the number of exacerbations were significantly lower in the sputummanagement group than in the clinical-management group. The authors concluded that a treatment strategy directed at normalization of the induced sputum eosinophil count reduces asthma exacerbations and admissions, without the need for additional anti-inflammatory treatment. Comparable results were observed by Chlumsky et al. [36] and Jayaram et al. [37], who applied a similar strategy with 55 and 117 asthma patients, respectively, but with follow-up periods of 18 and 24 months, respectively (table 1). Based mainly on these 3 studies, a recent systematic review and meta-analysis concluded that the tailoring of asthma treatment based on sputum eosinophils is indeed useful in reducing asthma exacerbations [38].

This finding may be related to the recent observation that bronchial inflammation may persist after years of disease evolution in patients with well-controlled asthma. In a recent cross-sectional study conducted on 84 adult patients with an Asthma Control Questionnaire score of $<0.75$ and with no exacerbations in the previous year, persistent bronchial inflammation was documented in 59 patients (66\%): 28 cases were considered eosinophilic, 28 neutrophilic and 3 as mixed [11]. Similar findings have been reported by other authors. In a population of 76 adult patients with total asthma control based on GINA/NIH guidelines, Hanxiang et al. [39] observed higher levels of eosinophils, eosinophil cationic protein and IL-5 in comparison with healthy subjects, suggesting that airway inflammation persists during total asthma control. Madhuban et al. [40] reported similar results in a pediatric population with well-controlled asthma and presenting with
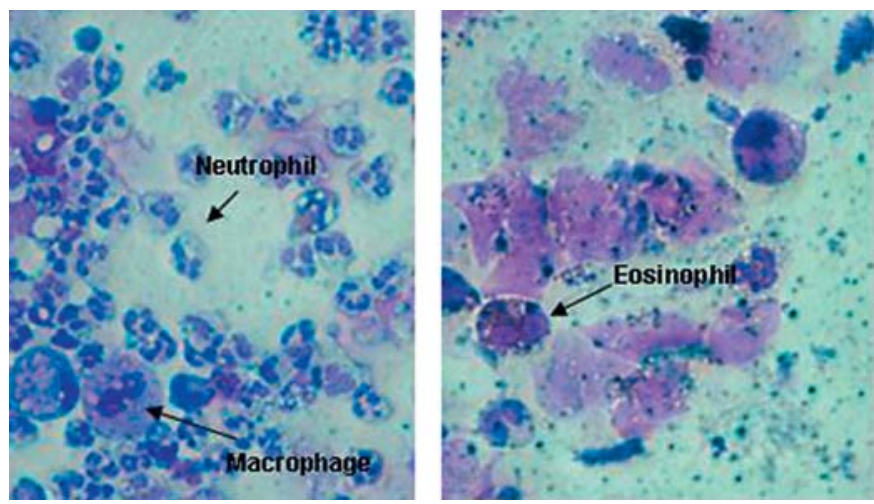

Fig. 1. Cell types that can be found in induced sputum samples.

Table 1. Generals characteristics of the 3 studies included in most reviews on the utility of adjusting asthma treatment based on the eosinophil count in induced sputum

\begin{tabular}{|c|c|c|c|}
\hline & $\begin{array}{l}\text { Green } \\
\text { et al. [35] }\end{array}$ & $\begin{array}{l}\text { Chlumsky } \\
\text { et al. [36] }\end{array}$ & $\begin{array}{l}\text { Jayaram } \\
\text { et al. [37] }\end{array}$ \\
\hline \multirow[t]{2}{*}{ Patients, $\mathrm{n}$} & A: 37 & A: 30 & A: 50 \\
\hline & B: 37 & B: 21 & B: 52 \\
\hline \multirow[t]{3}{*}{ Age, years } & A: 36 & A: 42 & A: 46 \\
\hline & B: 32 & B: 48 & B: 43 \\
\hline & (median) & (mean) & (mean) \\
\hline \multirow{2}{*}{ Male sex, $\mathrm{n}$} & A: 19 & A: 13 & A: 15 \\
\hline & B: 21 & B: 6 & B: 15 \\
\hline \multirow[t]{2}{*}{ Asthma severity } & Moderate & Moderate & Mild \\
\hline & to severe & to severe & $\begin{array}{l}\text { Moderate } \\
\text { to severe }\end{array}$ \\
\hline \multirow{2}{*}{$\begin{array}{l}\mathrm{FEV}_{1}, \% \text { predicted } \\
\text { (mean) }\end{array}$} & A: 73.4 & A: 71.8 & A: 78.4 \\
\hline & B: 75.9 & B: 71.3 & B: 78.7 \\
\hline Follow-up, months & 12 & 18 & 24 \\
\hline \multirow{3}{*}{$\begin{array}{l}\text { Sputum eosinophils } \\
\text { at baseline, } \%\end{array}$} & A: 2.4 & A: 9 & A: 2 \\
\hline & B: 2.0 & B: - & B: 2 \\
\hline & $\begin{array}{l}\text { (geometric } \\
\text { mean) }\end{array}$ & & (median) \\
\hline \multirow{3}{*}{$\begin{array}{l}\text { Inhaled steroids, } \\
\mu \mathrm{g} / \text { day }\end{array}$} & A: 1,930 & A: 1,695 & A: 500 \\
\hline & B: 1,680 & B: 1,418 & B: 500 \\
\hline & (mean) & (mean) & (median) \\
\hline \multirow{3}{*}{$\begin{array}{l}\text { Exacerbations } \\
\text { during study, } n\end{array}$} & A: 35 & A: 0.22 & A: 47 \\
\hline & B: 109 & B: 0.78 & B: 79 \\
\hline & (total) & $\begin{array}{l}\text { (per patient } \\
\text { per year) }\end{array}$ & (total) \\
\hline
\end{tabular}

$\mathrm{A}=$ Treatment based on eosinophil count; $\mathrm{B}=$ treatment according to clinical guidelines.

${ }^{1}$ The majority of patients were classified as moderate to severe. 
exercise-induced bronchoconstriction. In these studies, asthma control and treatment were carried out in accordance with clinical guidelines; therefore, it is not surprising that all subjects presented with bronchial inflammation.

These considerations are particularly relevant in the case of patients with severe asthma, for whom sputum cell analysis is probably the most useful [41]. The international European Respiratory Society/American Thoracic Society (ERS/ATS) guidelines for the definition, evaluation and treatment of severe asthma in patients have established that the treatment of adults with severe asthma should be guided by clinical criteria and sputum eosinophil counts performed at centers with experience in the use of this technique, rather than by clinical criteria alone [19]. The authors emphasize that the use of sputum eosinophil counts to guide therapy for adults 'places a higher value on possible clinical benefits from adjusting the treatment in selected patients and on avoidance of inappropriate escalation of treatment and a lower value on increased use of resources'. Patients who are likely to benefit from this approach are those who can produce sputum, demonstrate persistent or at least intermittent eosinophilia and have severe asthma with frequent exacerbations [19].

\section{Studies Conducted on Exhaled Air}

\section{Exhaled Nitric Oxide}

Nitric oxide (NO), a small gaseous free radical, is the most extensively studied of the noninvasive exhaled markers of airway inflammation. In the respiratory tract, NO is produced by a wide variety of cell types, including epithelial cells, airway nerves, inflammatory cells and vascular endothelial cells [42]. It is generated by the conversion of $\mathrm{L}$-arginine to L-citrulline, catalyzed by enzymes known as nitric oxide synthases (NOS). NOS exist as 3 distinct isoforms, constitutive neural NOS, constitutive endothelial NOS and inducible (i)NOS [43]. High concentrations of iNOS-derived NO have been implicated in nonspecific host defense mechanisms against pathogens as well as in chronic inflammatory diseases, and iNOS is the key isoform in the study and treatment of asthma [44]. The levels of $\mathrm{NO}$ can be measured repeatedly in exhaled breath (i.e. exhaled NO, FeNO), using a range of commercially available analyses. Recommendations outlining standardized procedures for adequate FeNO measurement have been published by a task force of the ATS and ERS [45].

Several applications have been attributed to FeNO in relation to bronchial asthma. Among them are its possi- ble use as an inflammatory marker or identifier of phenotypes in the diagnosis, monitoring and management of asthma patients, or as a marker of compliance with treatment. Currently, there are no reference values for FeNO; a guide prepared by the ATS suggested that cut-off points should be established depending on the aim of the test (e.g. diagnosis of asthma and control of the disease), and taking into account the equipment used and the condition of each individual patient [46].

In relation to use as an inflammatory marker, high levels of FeNO have been observed in asthma patients compared to healthy controls and, in particular, in atopic versus nonatopic asthma patients [47]. Several studies have shown a significant correlation between FeNO levels and eosinophil count in sputum, bronchoalveolar lavage fluid or bronchial biopsies in asthma patients, suggesting that FeNO may be an important marker of eosinophilic inflammation [48-51]. This possibility is corroborated by the fact that the relationship between FeNO and esonophilic inflammation is probably independent of the underlying pathology, as has also been demonstrated in patients with COPD [52, 53], eosinophilic bronchitis [54] or in atopic patients with allergic rhinitis [47]. It is known that corticosteroid treatment decreases the number of eosinophils in the airways of asthma patients. Bearing in mind the relationship between FeNO and eosinophilic inflammation, some authors have suggested that FeNO levels may predict the response to corticosteroid treatment [55].

The identification of phenotypes in patients with bronchial asthma and of phenotype-specific biomarkers that can predict responses to different treatments is the current goal of asthma management [56]. Recently, Hanania et al. [57] observed that in patients with severe asthma treated with omalizumab, FeNO levels may predict the response to treatment. In patients with severe asthma, the identification of phenotypes may be particularly relevant. Associations between FeNO and asthma severity has been reported. Among patients with severe asthma, FeNO identifies the most reactive asthma phenotype [58]. Moreover, FeNO levels are higher in patients with refractory asthma and the eosinophilic phenotype [28]. Amelink et al. [59] recently suggested that the association of adult-onset, severe, nonatopic asthma and persistent eosinophilic airway inflammation related to high FeNO levels indicates a specific phenotype. Another specific phenotype, according to cluster analysis, is adult-onset, severe, nonatopic asthma, obesity and a low level of FeNO $[9,60]$.

Several studies have examined the utility of FeNO measurement as a diagnostic test for asthma [61-66]. Re- 
Table 2. Utility of FeNO measurement as a diagnostic test for asthma

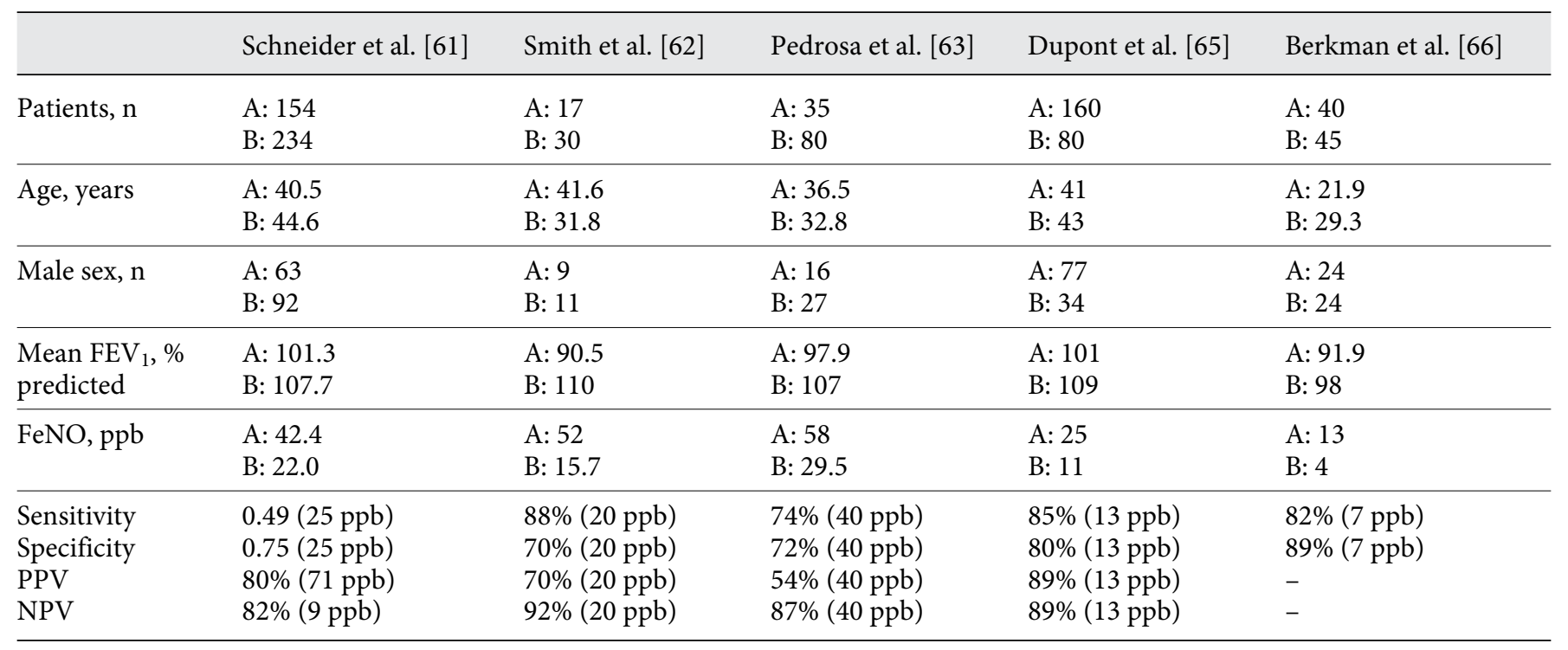

$\mathrm{A}=$ Asthma $\mathrm{B}=$ no asthma; NPV = negative predictive value; $\mathrm{PPV}=$ positive predictive value.

sults are mixed, with the sensitivity ranging between 72 and $88 \%$ and the specificity between 64 and $88 \%$ (table 2). Nevertheless, several guidelines advocate the use of FeNO as a diagnostic test $[8,46]$. Specifically, the ATS guidelines state that FeNO values $>50 \mathrm{ppb}$ in adults and $>35 \mathrm{ppb}$ in children can predict asthma [46], while the Spanish guidelines set the cut-off point at $30 \mathrm{ppb}$ [8]. However, the diagnostic role of $\mathrm{FeNO}$ is limited, principally because airway inflammation in asthma is not always associated with increased FeNO levels [67].

The use of FeNO has also been proposed for the control and management of asthma. Some studies propose adjusting the treatment according to the FeNO levels rather than according to clinical recommendations as most guidelines suggest $[68,69]$. However, these results have not been reproduced by other groups (table 3 ) [70, 71]. A recent meta-analysis on the efficacy of tailoring asthma interventions based on FeNO values showed that the benefits of the FeNO strategy were not statistically significant for asthma exacerbations, but that it did allow a reduction in the final daily inhaled corticosteroid dose in adults [38].

Finally, recent investigations have shown the ability of FeNO measurements to predict the response to steroid therapy, especially in cases in which control of the disease is difficult $[72,73]$. In asthma patients with high levels of FeNO and uncontrolled disease demonstrated by the Asthma Control Questionnaire or the Asthma Control Test questionnaire, inadequate treatment should be suspected, either due to patient noncompliance or to inappropriate prescription by the doctor. Conversely, if the FeNO measurement in this situation is low, an alternative diagnosis, the influence of comorbidities, resistance to drug action or noneosinophilic phenotypes should all be considered [67].

\section{Volatile Organic Compounds}

A relatively new, noninvasive technique for assessing airway inflammation involves the profiling of volatile organic compounds (VOCs) in exhaled breath. VOCs are chemicals that contain carbon and have a high vapor pressure when in contact with the atmosphere. In patients with asthma, the production of reactive oxygen species (ROS) is increased [74], causing lipid peroxidation of cell membranes and the subsequent production of VOCs [75]. Exhaled air is a mixture of thousands of VOCs. The identification and quantification of individual VOCs requires laboratory methodologies employing gas chromatography coupled with mass spectometry [76]. An alternative to the individual quantification of each VOC is joint measurement by Electronic Nose (ENose) technology. ENose exploits arrays of broadly cross-reactive sensors, responding to a variety of VOCs in a highly sensitive and reversible manner within a short response time. ENose generates a molecular profile of the VOC mixture in exhaled breath, also called the 'breathprint', and allows analysis by pattern recognition algorithms for discrimi- 
Table 3. General characteristics of the 4 studies discussed in the text on the utility of adjusting asthma treatment based on levels of FeNO

\begin{tabular}{|c|c|c|c|c|}
\hline & Jones et al. [68] & Smith et al. [69] & Szefler et al. [70] & de Jongste et al. [71] \\
\hline Patients, $\mathrm{n}$ & 78 & $\begin{array}{l}\text { A: } 46 \\
\text { B: } 48\end{array}$ & $\begin{array}{l}\text { A: } 276 \\
\text { B: } 270\end{array}$ & $\begin{array}{l}\text { A: } 77 \\
\text { B: } 74\end{array}$ \\
\hline Mean age, years & 43 & 44.8 & $\begin{array}{l}\text { A: } 14.4 \\
\text { B: } 14.4\end{array}$ & $\begin{array}{l}\text { A: } 11.6 \\
\text { B: } 11.8\end{array}$ \\
\hline Asthma severity & Mild to moderate & $\begin{array}{l}\text { Mild } \\
\text { Moderate to severe }\end{array}$ & $\begin{array}{l}\text { Mild } \\
\text { Moderate to severe }\end{array}$ & $\begin{array}{l}\text { Mild } \\
\text { Moderate to severe }\end{array}$ \\
\hline Mean $\mathrm{FEV}_{1}, \%$ predicted & 92.0 & $\begin{array}{l}\text { A: } 86.4 \\
\text { B: } 83.1\end{array}$ & $\begin{array}{l}\text { A: } 95.9 \\
\text { B: } 95.7\end{array}$ & $\begin{array}{l}\text { A: } 88 \\
\text { B: } 88\end{array}$ \\
\hline $\begin{array}{l}\text { Inhaled steroids, } \\
\mu \mathrm{g} / \text { day during the study }\end{array}$ & $\begin{array}{l}100-1,600 \\
\text { (range) }\end{array}$ & $\begin{array}{l}\text { A: } 370 \\
\text { B: } 641 \\
\text { (mean; fluticasone) }\end{array}$ & $\begin{array}{l}\text { A: } 550 \\
\text { B: } 450 \\
\text { (mean; fluticasone) }\end{array}$ & $\begin{array}{l}\text { A: } 250-1,000 \\
\text { B: } 250-600 \\
\text { (range) }\end{array}$ \\
\hline Exacerbations & $\begin{array}{l}78 \% \\
\text { (loss of control) }\end{array}$ & $\begin{array}{l}\text { A: } 0.49 \\
\text { B: } 0.90 \\
\text { (patient/year) }\end{array}$ & $\begin{array}{l}\text { A: } 37 \\
\text { B: } 44 \\
\text { (\% of patients) }\end{array}$ & $\begin{array}{l}\text { A: } 9 \\
\text { B: } 12 \\
\text { (number of patients } \\
\text { with } \geq 1 \text { exacerbations) }\end{array}$ \\
\hline
\end{tabular}

$\mathrm{A}=$ FeNO group; $\mathrm{B}=$ symptom group.

nating between 'breathprints' without identifying the individual analytes [77].

Patterns of VOCs, as detected by ENose, can distinguish between patients with asthma and controls [78], and between patients with asthma and those with COPD [79]. Recently, Ibrahim et al. [80] observed that distinct patterns of VOCs detected by chromatography and mass spectometry analysis differentiated between the breath of patients with asthma and that of healthy controls, and identified clinically relevant disease phenotypes such as sputum eosinophilia. They also concluded that exhaled VOCs have potential for use as noninvasive biomarkers for asthma, and may provide novel pathophysiological insights. Recently, Robroeks et al. [81] also demonstrated that a combination of different exhaled VOCs is able to predict exacerbations of childhood asthma.

Further studies are needed for external validation of these results in larger patient samples and in order to investigate whether better asthma control can be achieved when VOC analysis in exhaled breath is included as a parameter in daily clinical practice. The effect of smoking should also be standardized, as it has recently been demonstrated that although the majority of VOCs are found in very low concentrations when comparing the effect of smoking in healthy individuals, levels of nonanal are high in both current smokers and exsmokers [82]. This compound is a byproduct of the breakdown of the cell membrane, and its identification in this context indicates alveolar cell damage in individuals exposed to tobacco smoke.

\section{Exhaled Breath Temperature}

Recently, certain authors have explored the usefulness of measuring the temperature of exhaled breath as a marker of inflammation in asthma patients compared with $\mathrm{FEV}_{1}$ or other inflammatory markers such as FeNO or eosinophils in sputum [83-87]. It has been hypothesized that bronchial inflammatory processes may cause vascular dilation and increase bronchial blood flow, which may be responsible for the increase in exhaled breath temperature in asthma patients [88, 89].

Three methods have been put forward to assess exhaled breath temperature. Paredi et al. [83] measured the tem- 
perature increase mathematically in a slow and controlled maneuver at a flow of between 10 and 11 liters/min and a mouth pressure of $10 \mathrm{~cm} \mathrm{H}_{2} \mathrm{O}$. The temperature of the exhaled air during expiration rises exponentially. The point at $63 \%$ of the total temperature increase is chosen to study the slope of the maximal temperature change, thus allowing a better mathematical characterization of the tracings before the plateau. Piacentini et al. [84] measured the temperature in a slow maneuver with an uncontrolled flow, identifying the maximum temperature observed in the exhaled air and the plateau temperature at the end of an exhalation maneuver. Finally, Popov et al. [85] designed a device (X-halo) which achieves a plateau temperature within 3-4 min, representing the value of exhaled air temperature, where patients breathe at tidal volume, inhale through the nose and exhale through a mouthpiece into the chamber.

Recently, Svensson et al. $[88,90]$ showed that exhaled breath temperature increases after exercise as well as after both eucapnic voluntary hyperventilation and methacholine challenge tests. In all cases, this is related to the fall in both $\mathrm{FEV}_{1}$ and the oral temperature, suggesting a vascular response. Interestingly, no differences are seen between asthmatics and healthy controls, indicating that the increase in exhaled breath temperature is mainly physiological rather than pathophysiological. Further studies are required to establish the true role of this potential biomarker in bronchial asthma.

\section{Exhaled Breath Condensate}

Exhaled breath condensate (EBC) is the liquid phase of exhaled air. It is sampled noninvasively by cooling or freezing exhaled air with the use of special condensing devices, allowing the collection of condensed water vapor, nonvolatile substances that are released in aerosol particles and volatile substances in a gas phase [91]. It is a simple technique in which the subject breathes tidally. The collection of EBC does not disturb the underlying disease process, a fact that makes it a useful approach for crossday variation studies, assessing epidemiological and pharmacological therapies and longitudinal studies that monitor airway inflammation [92]. Moreover, evidence is emerging that abnormalities in EBC composition may reflect biochemical changes in the airway lining fluid [93].

Asthma is the chronic inflammatory disease in which $\mathrm{EBC}$ has been most widely used, especially EBC $\mathrm{pH} . \mathrm{pH}$ measurement using electrodes after removing the $\mathrm{CO}_{2}$ by sparging with a noble gas is a validated technique with proven reproducibility and robustness and has potential for clinical use. However, there are doubts as to whether this measurement reflects the degree of actually existing acidification in the distal airway and/or lung parenchyma. The possibility that the high production of ammonium in the oral cavity may affect the measurement cannot be ignored. It is generally accepted that the $\mathrm{pH}$ obtained is a mean value of the acidification status of the entire airway [94]. The $\mathrm{pH}$ measurement is not affected by hyperventilation, the temperature of sample collection or the duration of the process, but it is affected by the equipment used to obtain $\mathrm{EBC}$ [95]. In healthy subjects, the $\mathrm{pH}$ is approximately 7.7 , with a range of 7.4-8.8. However, as mentioned above, these values depend on the age of the patient, e.g. the normal range in individuals of $60-80$ years of age is 5.28-7.81 [96].

Various studies have demonstrated that $\mathrm{pH}$ values in patients with stable asthma are similar to those observed in the healthy population, although they may be lower in cases of treatment-refractory, severe asthma. A marked decrease in $\mathrm{pH}$ has been observed in exacerbations, which then returns to the baseline level once medical treatment is initiated $[97,98]$. To date, it has not been shown to be useful in the control of asthma, but some authors have suggested that $\mathrm{pH}$ monitoring by patients at home may help to optimize inhaled corticosteroid treatment. Although there is no evidence that a particular $\mathrm{pH}$ level is related to the underlying cell type, it has been suggested that there may be a correlation with the number of eosinophils obtained in induced sputum and with parameters expressing oxidative and nitrosative stress in the EBC itself [99].

Recently, it was suggested that assessment of $\mathrm{pH}$ may be useful for evaluating patients with work-related asthma. It was observed that falls in $\mathrm{pH}$ of $>0.4$ when comparing working periods to off-work periods has a sensitivity of $40 \%$ and a specificity of $90 \%$ for the diagnosis of occupational asthma, and that analyzing fluctuations in $\mathrm{pH}$ in conjunction with peak expiratory flow improves the diagnostic yield [100]. It has also been reported that a decrease in $\mathrm{pH}$ of 0.4 after a specific challenge test has a sensitivity of $79 \%$ and a specificity of $100 \%$ for the diagnosis of work-exacerbated asthma [101].

Oxidative stress is a nonspecific feature of the inflammatory process. Increased production of ROS by eosinophils, neutrophils, macrophages and other inflammatory cells may cause bronchial hyperresponsiveness, a key feature of asthma [102]. Although increased levels of aldehydes, nitrosothiols, nitrotyrosine and especially NO have been detected in the EBC of asthma patients, 8 -isoprostane (8-IP) and hydrogen peroxide $\left(\mathrm{H}_{2} \mathrm{O}_{2}\right)$ are the biomarkers which have been most studied with this meth- 
Table 4. The most important biomarkers of EBC in asthma patients

\begin{tabular}{lllll}
\hline & Stable asthma & Exacerbations & Smoking habit & Atopy \\
\hline $\mathrm{pH}$ & decreases & decreases & decreases & decreases \\
$\mathrm{H}_{2} \mathrm{O}_{2}$ & increases & increases & increases & no changes \\
$8-\mathrm{IP}$ & increases & increases & - & - \\
$\mathrm{NOx}$ & increases & - & decreases & increases \\
$\mathrm{PGs}$ & increases in $\mathrm{TxB}_{2}, \mathrm{PGE}_{2}{ }^{\mathrm{a}}, \mathrm{LXA} 4$ & - & increases & - \\
$\mathrm{LTs}$ & increases in LTB4 and Cys-LTs & increases in Cys-LTs & increases in LTB4 & increases in Cys-LTs \\
Cytokines & increases in IL4, IL8, IL17, TNF- $\alpha$ & increases in IL5 & - & - \\
\hline
\end{tabular}

$\mathrm{NOx}=$ Reactive nitrogen species; $\mathrm{TNF}=$ tumor necrosis factor; $\mathrm{Tx}=$ thromboxane.

${ }^{\text {a }} \mathrm{PGE}_{2}$ has a protective effect.

od in this population, with a view to their possible clinical application.

Significant correlations between the concentration of $\mathrm{H}_{2} \mathrm{O}_{2}$ in EBC and the eosinophil counts in induced sputum, disease severity [103], smoking habits [104] and the presence of symptoms in unstable asthma patients [99] have been reported. Inverse correlations have also been observed with $\mathrm{FEV}_{1}$ [105], peak expiratory flow [106] and $\mathrm{PC}_{20}$ in the methacholine test [103]. A recent study has shown that $\mathrm{H}_{2} \mathrm{O}_{2}$ values in adults with asthma are indeed higher than in the healthy population; they increase in accordance with the severity of the condition, and also reflect the administration of inhaled corticosteroid treatment. Although a nonsignificant trend was found, $\mathrm{H}_{2} \mathrm{O}_{2}$ levels did not seem to be affected by asthma control [107]. In fact, another recent study found no significant correlations between $\mathrm{H}_{2} \mathrm{O}_{2}$ levels and scores on the Asthma Control Test or FeNO level in stable asthma patients [108]. These last two findings, together with the wide variability that exists in the values of $\mathrm{H}_{2} \mathrm{O}_{2}$ concentrations in healthy individuals, may affect the clinical applicability of these observations.

Isoprostanes are compounds generated from the oxidation of arachidonic acid and are clear markers of oxidative stress. The form that has been studied the most is 8-IP. Although it has proven stable in exhaled air, recent studies have shown that it may not be detectable and that its levels vary widely, sometimes in association with age, in healthy individuals [96]. It is generally accepted that 8-IP levels are higher in patients with asthma than in healthy subjects [109], but it is not clear whether this increase is truly related to asthma severity or may, in fact, be due to the corticosteroid treatment [110]. The concentration of 8-IP increases in asthma exacerbations and is particularly high in cases of aspirin-induced asthma. In these cases, treatment with inhaled corticosteroids decreases its concentrations
[111]. While a correlation has been found between the levels of 8-IP and FeNO in patients with mild asthma but not in patients with severe asthma [109], a more interesting observation is the correlation with the involvement of the small airways, which indicates that 8-IP levels may reflect inflammation at this site and suggests that these levels should be measured in order to provide complementary information to spirometry in the monitoring of patients with bronchial asthma [112].

Leukotrienes (LTs), prostaglandins (PGs), lipoxins (LXs) and cytokines are specific features of the inflammatory process and can be measured in EBC (table 4). The PG that has been studied in the most depth using EBC is $\mathrm{PGE}_{2}$. Although no correlation has been found with the degree of bronchial hyperresponsiveness, nor is its concentration modified by the use of inhaled corticosteroids or anti-LTs, high levels of $\mathrm{PGE}_{2}$ appear to confer a protective bronchodilatory effect [113]. Cys-LTs, LTB4, interleukin (IL)4, IL5, IL8 and IL17, tumor necrosis factor- $\alpha$ and transforming growth factor- $\beta$ are all increased in the EBC of asthma patients compared with healthy individuals [114]. IL5 has also been proposed as a predictor of asthma exacerbations [115]. In a recent study, EBC LXA4 and LTB4 levels were increased in asthma patients compared with healthy control subjects. Although levels of both eicosanoids are increased in asthma patients, the LXA4/LTB4 ratio decreases with increasing asthma severity. Moreover, LXA4 EBC correlates with the degree of airflow obstruction measured using $\mathrm{FEV}_{1}$, and an LXA4 cut-off value of $7 \mathrm{pg} / \mathrm{ml}$ in EBC provides $90 \%$ sensitivity and $92 \%$ specificity for the diagnosis of asthma. An LTB4 cut-off value of $11 \mathrm{pg} / \mathrm{ml}$ in EBC provides $100 \%$ sensitivity and $100 \%$ specificity for the diagnosis of asthma [116]. In accordance with the idea that the activation of inflammatory cascades is accompanied by the generation of proresolving mediators, these findings support a role for EBC 
eicosanoid measurements in the noninvasive diagnosis of asthma, and suggest that proresolving eicosanoid pathways are dysregulated in patients with severe asthma.

\section{Conclusions}

Asthma is a chronic inflammatory disorder of the airways in which many cells and cellular elements play key roles. Chronic inflammation is associated with airway hyperresponsiveness and clinical symptoms. The idea of combining current clinical control and the assessment of the future risk has gained support in the last decade. The study of eosinophils in induced sputum has proved to be one of the most useful techniques in this regard, but the difficulty of its implementation in clinical practice means that it cannot be unreservedly recommended. Although initial studies suggested that the analysis of FeNO might be a good marker of the disease and that adjusting treatment according to FeNO levels might prevent exacerbations, this has not been confirmed in subsequent studies. Although the measurement of $\mathrm{pH}, \mathrm{H}_{2} \mathrm{O}_{2}$ and 8-IP in EBC is altered in patients with exacerbated asthma, further studies should be performed to assess whether these parameters can improve control of these patients. Studies should also be conducted to evaluate the value of volatile organic compound measurement and exhaled breath temperature.

The possibility of finding biomarkers that may help predict the risks of exacerbations and/or of lung function impairment to guide treatment choices is a primary objective in asthma research. Although the results reported so far are contradictory, it is worth exploring these avenues of research in more depth, given the prevalence of this disease.

\section{References}

1 Kazani S, Israel E: Update in asthma 2011. Am J Respir Crit Care Med 2012;186:35-40.

2 Bedolla-Barajas M, Morales-Romero J, Robles-Figeroa M, Fregoso-Fregoso M: Asthma in late adolescents of Western Mexico: prevalence and associated factors. Arch Bronchoneumol 2013;49:47-53.

3 Global Initiative for Asthma: Global strategy for asthma management and prevention 2012. http://www.ginasthma.com.

4 Martínez-Moratalla J, Almar E, Anto JM: Changes in asthma treatment in the Spanish Cohort of the European Community Respiratory Health Survey (ECRHS) from 19912001: a perspective over time. Arch Bronchoneumol 2013;49:113-118.

5 Martinez FD, Vercelli D: Asthma. Lancet 2013;382:1360-1372.

6 García Gomez M, Urbanos Garrido R, Castañeda Lopez R, Lopez Menduiña P: Direct health care costs of occupational asthma in Spain: an estimation from 2008. Arch Bronchoneumol 2012;48:355-361.

7 Taylor DR, Bateman ED, Boulet LP, Boushey HA, Busse WW, Casale TB, Chanez P, Enright PL, Gibson PG, de Jongste JC, Kerstjens HA, Lazarus SC, Levy ML, O’Byrne PM, Partridge MR, Pavord ID, Sears MR, Sterk PJ, Stoloff SW, Szefler SJ, Sullivan SD, Thomas MD, Wenzel SE, Reddel HK: A new perspective on concepts of asthma severity and control. Eur Respir J 2008;32:545-554.

8 Guía Española para el Manejo del Asma (GEMA 2009). http://www.gemasma.com.

9 Haldar P, et al: Cluster analysis and clinical asthma phenotypes. Am J Respir Crit Care Med 2008;178:218-224.

10 Moore WC, Meyers DA, Wenzel SE, Teague WG, Li H, Li X, D’Agostino R Jr, Castro M,
Curran-Everett D, Fitzpatrick AM, Gaston B, Jarjour NN, Sorkness R, Calhoun WJ, Chung KF, Comhair SA, Dweik RA, Israel E, Peters SP, Busse WW, Erzurum SC, Bleecker ER; National Heart, Lung, and Blood Institute's Severe Asthma Research Program: Identification of asthma phenotypes using cluster analysis in the Severe Asthma Research Program. Am J Respir Crit Care Med 2010;181:315323.

11 Muñoz X, Sanchez-Vidaurre S, Roca O, Torres F, Morell F, Cruz MJ: Bronchial inflammation and hyperresponsiveness in well controlled asthma. Clin Exp Allergy 2012;42: 1321-1328.

12 Wenzel SE, Schwart LB, Langmack EL, Halliday JL, Trudeau JB, Gibbs, RL, Chu HW: Evidence that severe asthma can be divided pathologically into two inflammatory subtypes with distinct physiologic and clinical characteristics. Am J Respir Crit Care Med 1999;160:1001-1008.

13 Volbeda F, Broekema M, Lodewijk ME, Hylkema MN, Reddel HK, Timens W, Postma DS, ten Hacken NH: Clinical control of asthma associates with measures of airway inflammation. Thorax 2013:68:19-24.

14 Wenzel SE: Asthma: defining of the persistent adult phenotypes. Lancet 2006;368:804-813.

15 Bruselle G, Maes T, Bracke KR: Eosinophils in the spotlight: eosinophilic airway inflammation in nonallergic asthma. Nat Med 2013:19: 977-979.

16 Haldar P, Brightling CE, Hargadon B, Gupta S, Monteiro W, Sousa A, Marshall RP, Bradding P, Green RH, Wardlaw AJ, Pavord ID: Mepolizumab and exacerbations of refractory eosinophilic asthma. N Engl J Med 2009;360: 973-984.
17 Corren J, Lemanske RF, Hanania NA, Korenblat PE, Parsey MV, Arron JR, Harris JM, Scheerens H, Wu LC, Su Z, Mosesova S, Eisner MD, Bohen SP, Matthews JG: Lebrikizumab treatment in adults with asthma. $\mathrm{N}$ Engl J Med 2011;365:1088-1098.

18 Wenzel SE, Ford L, Pearlman D, Spector S, Sher L, Skobieranda F, Wang L, Kirkesseli S, Rocklin R, Bock B, Hamilton J, Ming JE, Radin A, Stahl N, Yancopoulos GD, Graham N, Pirozzi G: Dupilumab in persistent asthma with elevated eosinophil levels. N Engl J Med 2013;368:2455-2466.

19 Chung KF, Wenzel SE, Brozek JL, Bush A, Castro M, Sterk PJ, Adcock IM, Bateman ED, Bel EH, Bleecker ER, Boulet LP, Brightling C, Chanez P, Dahlen SE, Djukanovic R, Frey U, Gaga M, Gibson P, Hamid Q, Jajour NN, Mauad T, Sorkness RL, Teague WG: International ERS/ATS guidelines on definition, evaluation and treatment of severe asthma. Eur Respir J 2014;43:343-373.

20 Sont JK, Willems LN, Bel EH, van Kricken JH, Vandenbroucke JP, Sterk PJ: Clinical control and histopathologic outcome of asthma when using airway hyperresponsiveness as an additional guide to long-term treatment. Am J Respir Crit Care Med 1999;159:1043-1051.

21 Perpiña M, García Río F, Álvarez Gutierrez FJ, Cisneros Serrano C, Compte Torrero L, Entrenas Costa LM, Melero Moreno C, Rodríguez Nieto MJ, Torrego Fernández A; Spanish Society of Pulmonology and Thoracic Surgery (SEPAR): Guidelines for the study of nonspecific bronchial hyperresponsiveness in asthma. Arch Bronconeumol 2013;49:432-446.

22 Davies AR, Hancox RJ: Induced sputum in asthma: diagnostic and therapeutic implications. Curr Opin Pulm Med 2013;19:60-65.
Asthma Control and Noninvasive

Inflammation Studies
Int Arch Allergy Immunol 2015;166:1-12 DOI: $10.1159 / 000371849$ 
23 Brightling CE: Cough due to asthma and nonasthmatic eosinophilic bronchitis. Lung 2010; 188(suppl 1):S13-S17.

24 Djukanovic R, Sterk PJ, Fahy JV, Hargreave FE: Standardised methodology of sputum induction and processing. Eur Respir J 2002; (suppl 37):1s-2s.

25 Pizzichini E, Pizzichini MM, Efthimiadis A, Evans S, Morris MM, Squillace D, Gleich GJ, Dolovich J, Hargreave FE: Indices of airway inflammation in induced sputum: reproducibility and validity of cell and fluid-phase measurements. Am J Respir Crit Care Med 1996;154:308-317.

26 Wadsworth S, Sin D, Dorscheid D: Clinical update on the use of biomarkers of airway inflammation in the management of asthma. J Asthma Allergy 2011;4:77-86.

27 Carroll N, Carello S, Cooke C, James A: Airway structure and inflammatory cells in fatal attacks of asthma. Eur Respir J 1996;4:709715 .

28 Hastie AT, Moore WC, Meyers DA, Vestal PL, Li H, Peters SP, Bleecker ER; National Heart, Lung, and Blood Institute Severe Asthma Research Program: Analyses of asthma severity phenotypes and inflammatory proteins in subjects stratified by sputum granulocytes. J Allergy Clin Immunol 2010;123:1028-1036.

29 Nair P, Pizzichini MM, Kjarsgaard M, Inman MD, Efthimiadis A, Pizzichini E, Hargreave FE, O’Byrne PM: Mepolizumab for prednisone-dependent asthma with sputum eosinophilia. N Engl J Med 2009;360:985-993.

30 Bacci E, Cianchetti S, Bartoli M, Dente FL, Di Franco A, Vagaggini B, Paggiaro P: Low sputum eosinophils predict the lack of response to beclomethasone in symptomatic asthmatic patients. Chest 2006;129:565-572.

31 Shannon J, Ernst P, Yamauchi Y, Olivenstein R, Lemiere C, Foley S, Cicora L, Ludwig M, Hamid Q, Martin JG: Differences in airway cytokine profile in severe asthma compared to moderate asthma. Chest 2008;133:420-426.

32 Al-Ramli W, Préfontaine D, Chouiali F, Martin JG, Olivenstein R, Lemière C, Hamid Q: $\mathrm{T}(\mathrm{H}) 17$-associated cytokines (IL-17A and IL17F) in severe asthma. J Allergy Clin Immunol 2009;123:1185-1187.

33 Butler CA, Heaney LG: Neurogenic inflammation and asthma. Inflamm Allergy Drug Targets 2007;6:127-132.

34 Pavord ID, Brightling CE, Woltmann G, Wardlaw AJ: Non-eosinophilic corticosteroid unresponsive asthma. Lancet 1999;353:2213 2214.

35 Green RH, Brightling CE, McKenna S, Hargadon B, Parker D, Bradding P, Wardlaw AJ, Pavord ID: Asthma exacerbations and sputum eosinophil count: a randomized controlled trial. Lancet 2002;360:1715-1721.

36 Chlumsky J, Striz I, Terl M, Vondracek J: Strategy aimed at reduction of sputum eosinophils decreases exacerbation rate in patients with asthma. J Int Med Res 2006;34:129-139.

37 Jayaram L, Pizzichini MM, Cook RJ, Boulet LP, Lemière C, Pizzichini E, Cartier A, Hus- sack P, Goldsmith $\mathrm{CH}$, Laviolette $\mathrm{M}$, Parameswaran K, Hargreave FE: Determining asthma treatment by monitoring sputum cell counts effect on exacerbations. Eur Respir J 2006;27:483-494.

38 Petsky HL, Cates CJ, Lasserson TJ, Li AM, Turner C, Kynaston JA, Chang AB: A systematic review and met-analysis: tailoring asthma treatment on eosinophilic markers (exhaled nitric oxide or sputum eosinophils). Thorax 2012;67:199-208.

39 Hanxiang N, Jiong Y, Yanwei C, Dunshuang W, Xuhong D, Xiaojun W, Changsheng L: Persistent airway inflammation and bronchial hyperresponsiveness in patients with totally controlled asthma. Int J Clin Pract 2008;62: 599-605.

40 Madhuban AA, Driessen JM, Brusse-Keizer MG, van Aalderen WM, de Jongh FH, Thio BJ: Association of the asthma control questionnaire with exercise-induced bronchoconstriction. J Asthma 2011;48:275-278.

41 Papaporfyriou A, Tseliou E, Loukides S, Kostikas K, Bakakos P: Noninvasive evaluation of airway inflammation in patients with severe asthma. Ann Allergy Asthma Immunol 2013; 110:316-321.

42 Ricciardolo FLM: Multiple roles of nitric oxide in the airways. Thorax 2003;58:175-182.

43 Nathan C, Xie QW: Nitric oxide synthases: roles, tolls, and controls. Cell 1994;78:915918.

44 Ricciardolo FL: Revisiting the role of exhaled nitric oxide in asthma. Curr Opin Pul Med 2014;20:53-59.

45 ATS/ERS recommendations for standardized procedures for the online and offline measurement of exhaled lower respiratory nitric oxide and nasal nitric oxide. Am J Respir Crit Care Med 2005;171:912-930.

46 Dweik RA, Boggs PB, Erzurum SC, Irvin CG, Leigh MW, Lundberg JO, Olin AC, Plummer AL, Taylor DR; American Thoracic Society Committee on Interpretation of Exhaled Nitric Oxide Levels (FENO) for Clinical Applications: An official ATS clinical practice guideline: interpretation of exhaled nitric oxide levels (FENO) for clinical applications. Am J Respir Crit Care Med 2011;184:602615.

47 Jouaville LF, Annesi-Maesano I, Nguyen LT, Bocage AS, Bedu M, Caillaud D: Interrelationships among asthma, atopy, rhinitis and exhaled nitric oxide in a population-based sample of children. Clin Exp Allergy 2003;33: 1506-1511.

48 Strunk RC, Szefler SI, Philips BR, Zeiger RS, Chinchilli VM, Larsen G, Hodgdon K, Morgan W, Sorkness CA, Lemanske RF Jr; Childhood Asthma Research and Education Network of the National Heart, Lung, and Blood Institute: Relationship of exhaled nitric oxide to clinical and inflammatory markers of persistent asthma in children. J Allergy Clin Immunol 2003;112:883-892.

49 Berry MA, Shaw DE, Green RH, Brightling CE, Wardlaw AJ, Pavord ID: The use of ex- haled nitric oxide concentrations to identify eosinophilic airway inflammation: an observational study in adults with asthma. Clin Exp Allergy 2005;35:1175-1179.

50 Warke TJ, Fitch PS, Brown V, Taylor R, Lyons JD, Ennis M, Shields MD: Exhaled nitric oxide correlates with airways eosinophils in childhood asthma. Thorax 2002;57:383-387.

51 Lemière $C$, Ernst $P$, Olivenstein R, Yamauchi Y, Govindaraju K, Ludwig MS, Martin JG, Hamid Q: Airway inflammation assessed by invasive and non-invasive means in severe asthma: eosinophilic and non-eosinophilic phenotypes. J Allergy Clin Immunol 2006; 118:1033-1039.

52 Fabbri LM, Romagnoli M, Corbetta L, Casoni G, Busljetic K, Turato G, Ligabue G, Ciaccia A, Saetta M, Papi A: Differences in airway inflammation in patients with fixed airflow obstruction due to asthma or chronic obstructive pulmonary disease. Am J Respir Crit Care Med 2003;167:418-424.

53 Soler-Cataluña JJ, Cosio B, Izquierdo JL, Lopez-Campos JL, Marin JM, Agüero R, Baloira A, Carrizo S, Esteban C, Galdiz JB, González MC, Miravitlles M, Monsó E, Montemayor T, Morera J, Ortega F, Peces-Barba G, Puente L, Rodríguez JM, Sala E, Sauleda J, Soriano JB, Viejo JL: Consensus document on the overlap phenotype COPD-asthma in COPD. Arch Bronconeumol 2012;48;331-337.

54 Brightling CE, Symon FA, Birring SS, Bradding P, Wardlaw AJ, Pavord ID: Comparison of airway immunopathology of eosinophils bronchitis and asthma. Thorax 2003;58:528532.

55 Smith AD, Cowan JO, Brassett KP, Filsell S, McLachlan C, Monti-Sheehan G, Herbison GP, Taylor DR: Exhaled nitric oxide: a predictor of steroid response. Am J Respir Crit Care Med 2005;172:453-459.

56 Quirce S, Bobolea I, Domínguez-Ortega J, Barranco P: Future biologic therapies in asthma. Arch Bronconeumol 2014;50:355361

57 Hanania NH, Wenzel S, Rosén K, Hsieh HJ Mosesova S, Choy DF, Lal P, Arron JR, Harris JM, Busse W: Exploring the effects of omalizumab in allergic asthma: an analysis of biomarkers in the EXTRA study. Am J Respir Crit Care Med 2013;187:804-811.

58 Dweik RA, Sorkness RL, Wenzel S, Hammel J, Curran-Everett D, Comhair SA, Bleecker E, Busse W, Calhoun WJ, Castro M, Chung KF, Israel $\mathrm{E}$, Jarjour $\mathrm{N}$, Moore $\mathrm{W}$, Peters $\mathrm{S}$, Teague G, Gaston B, Erzurum SC; National Heart, Lung, and Blood Institute Severe Asthma Research Program: Use of exhaled nitric oxide measurement to identify a reactive at-risk phenotype among patients with asthma. Am J Respir Crit Care Med 2010; 181:1033-1041.

59 Amelink M, de Groot JC, de Nijs SB, Lutter R, Zwinderman AH, Sterk PJ, ten Brinke A, Bel $\mathrm{EH}$ : Severe adult-onset asthma: a distinct phenotype. J Allergy Clin Immunol 2013;132: 336-341. 
60 Erkoçoğlu M, Kaya A, Ozcan C, Akan A, Vezir E, Azkur D, Kara O, Demirel F, Ginis T, Civelek E, Kocabaş CN: The effect of obesity on the level of fractional exhaled nitric oxide in children with asthma. Int Arch Allergy Immunol 2013;162:156-162.

61 Schneider A, Schwarzbach J, Faderl B, Welker L, Karsch-Völk M, Jörres RA: FENO measurement and sputum analysis for diagnosing asthma in clinical practice. Respir Med 2013; 107:209-218.

62 Smith AD, Cowan JO, Filsell S, McLachlan C, Monti-Sheehan G, Jackson P, Taylor DR: Diagnosing asthma: comparisons between exhaled nitric oxide measurements and conventional test. Am J Respir Crit Care Med 2004; 169:473-478.

63 Pedrosa M, Cancelliere N, Barranco P, LopezCarrasco V, Quirce S: Usefulness of exhaled nitric oxide for diagnosing asthma. J Asthma 2010;47:817-821.

64 Sandrini A, Taylor DR, Thomas PS, Yates DH: Fractional exhaled nitric oxide in asthma: an update. Respirology 2010;15:57-70.

65 Dupont LJ, Demedts MG, Verleden GM: Prospective evaluation of the validity of exhaled nitric oxide for the diagnosis of asthma. Chest 2003;123:751-756.

66 Berkman N, Avital A, Breuer R, Bardach E, Springer C, Godfrey S: Exhaled nitric oxide in the diagnosis of asthma: comparison with bronchial provocation tests. Thorax 2005;60: 383-388.

67 Perez de Llano LA: Nitric oxide (NO) in managing asthma. Arch Bronconeumol 2012;48: 35-36.

68 Jones SL, Kittelson J, Cowan JO, Flannery EM, Hancox RJ, McLachlan CR, Taylor DR The predictive value of exhaled nitric oxide measurements in assessing changes in asthma control. Am J Respir Crit Care Med 2001;164: 738-743.

69 Smith AD, Cowan JO, Brassett KP, Herbison GP, Taylor DR: Use of exhaled nitric oxide measurements to guide treatment in chronic asthma. N Engl J Med 2005;352:2163-2173.

70 Szefler SJ, Mitchell H, Sorkness CA, Gergen PJ, O’Connor GT, Morgan WJ, Kattan M, Pongracic JA, Teach SJ, Bloomberg GR, Eggleston PA, Gruchalla RS, Kercsmar CM, Liu AH, Wildfire JJ, Curry MD, Busse WW: Management of asthma based on exhaled nitric oxide in addition to guideline-based treatment for inner-city adolescents and young adults: a randomised controlled trial. Lancet 2008;372:1065-1072.

71 de Jongste JC, Carraro S, Hop WC; CHARISM Study Group, Baraldi E: Daily telemonitoring of exhaled bitric oxide and symptoms in the treatment of childhood asthma. Am J Respir Crit Care Med 2009;179:93-97.

72 Cowan DC, Cowan JO, Palmay R, Williamson A, Taylor DR: Effects of steroid therapy in inflammatory cell subtypes in asthma. Thorax 2010;65:384-390.

73 Perez de Llano JA, Carballada F, Castro Añón O, Pizarro M, Golpe R, Baloira A, Vázquez
Caruncho M, Boquete M: Exhaled nitric oxide predicts control in patients with difficultto-treat asthma. Eur Respir J 2010;35:12211227.

74 Rahman I, Kelly F: Biomarkers in breath condensate: a promising new non-invasive technique in free radical research. Free Radic Res 2003;1253-1266.

75 Kinnula VI: Production and degradation of oxygen metabolites during inflammatory states in the human lung. Curr Drug Targets Inflamm Allergy 2005;4:465-470.

76 Moser B, Bodrogi F, Eibl G, Lechner M, Rieder J, Lirk P: Mass spectrometric profile of exhaled breath-field study by PTR-MS. Respir Physiol Neurobiol 2005; 145:295300.

77 Röck F, Barsan N, Weimar U: Electronic nose: current status and future trends. Chem Rev 2008;108:705-725.

78 Dragonieri S, Schot R, Mertens BJ, Le Cessie S, Gauw SA, Spanevello A, Resta O, Willard NP, Vink TJ, Rabe KF, Bel EH, Sterk PJ: An electronic nose in the discrimination of patients with asthma and controls. J Allergy Clin Immunol 2007;120:856-862.

79 Fons N, Zwinderman AH, van der Schee MP, de Nijs SB, Dijkers E, Roldaan AC, Cheung D, Bel EH, Sterk PJ: Exhaled breath profiling enables discrimination of chronic obstructive pulmonary disease and asthma. Am J Respir Crit Care Med 2008;180:10761082

80 Ibrahim B, Basanta M, Cadden P, Sinh D, Douce D, Woodcock A, Fowler SJ: Non-invasive phenotyping using exhaled volatile organic compounds in asthma. Thorax 2011;66: 804-809.

81 Robroeks ChM, van Berkel JJ, Jöbsis Q, van Schooten FJ, Dallinga JW, Wouters EF, Dompeling E: Exhaled volatile organic compounds predict exacerbations of childhood asthma in 1-year prospective study. Eur Respir J 2013; 42:98-106.

82 Jareño JJ, Muñoz MA, Carrillo B, Maldonado JA, de Grande I, Aguilar A, Civera C, Gutierrez C, Callol LM: Volatile organic compounds in exhaled breath in a healthy population: effect of tobacco smoking. Arch Bronconeumol 2013;49:457-461.

83 Paredi P, Kharitonov SA, Barnes PJ: Faster rise of exhaled breath temperature in asthma. Am J Respir Crit Care Med 2002;165:181184.

84 Piacentini GL, Bodini A, Zerman L, Costella S, Zanolla L, Peroni DG, Boner AL: Relationship between exhaled air temperature and exhaled nitric oxide in childhood asthma. Eur Respir J 2002;20:108-111.

85 Popov TA, Dunev S, Kralimarkova TZ, Kraeva S, DuBuske LM: Evaluation of a simple potentially individual device for exhaled breath temperature measurement. Respir Med 2007; 101:2044-2055

86 Piacentini GL, Bodini A, Peroni D, Ress M, Costella S, Boner AL: Exhaled air temperature and eosinophil airway inflammation in aller- gic asthmatic children. J Allergy Clin Immunol 2004;114:202-204.

87 Kralimarkova TZ, Popov TA: Exhaled breath temperature: broadening the horizons. Int J Tuberc Lung Dis 2014;18:250-251.

88 Svensson H, Bjermer L, Tufvesson E: Exhaled breath temperature in asthmatics and controls after eucapnic voluntary hyperventilation and methacholine challenge test. Respiration 2014;87:149-157.

89 Paredi P, Kharitoov SA, Barnes PJ: Correlation of exhaled breath temperature with bronchial blood flow in asthma. Respir Res 2005;6: 15.

90 Svensson H, Nilsson D, Bjermer L, Tufvesson E: Exhaled breath temperature after exercise in asthmatics and controls. Respiration 2012; 84:283-290.

91 Hoffmeyer F, Raulf-Heimoth M, Brüning T: Exhaled breath condensate and airway inflammation. Curr Opin Allergy Clin Immunol 2009;9:16-22.

92 Horvath I, Hunt J, Barnes PJ, Alving K, Antczak A, Baraldi E, Becher G, van Beurden WJ, Corradi M, Dekhuijzen R, Dweik RA, Dwyer T, Effros R, Erzurum S, Gaston B, Gessner C, Greening A, Ho LP, Hohlfeld J, Jöbsis Q, Laskowski D, Loukides S, Marlin D, Montuschi $\mathrm{P}$, Olin AC, Redington AE, Reinhold P, van Rensen EL, Rubinstein I, Silkoff P, Toren K, Vass G, Vogelberg C, Wirtz H; ATS/ERS Task Force on Exhaled Breath Condensate: Exhaled breath condensate; methodological recommendations and unresolved questions. Eur Respir J 2005;26:523-548.

93 Kostikas K, Koutsokera A, Papiris S, Gourgoulianis KI, Loukides S: Exhaled breath condensate in patients with asthma: implications for application in clinical practice. Clin Exp Allergy 2008;38:557-565.

94 Vaughan J, Ngamtrakulpanit L, Pajewski TN, Turner R, Nguyen TA, Urban P, Hom S, Gaston $\mathrm{B}$, Hunt J: Exhaled breath condensate $\mathrm{pH}$ is a robust and reproducible assay of airway acidity. Eur Respir J 2003;22:889-894.

95 Prieto L, Ferrer A, Palop J, Domenech J, Llusar R, Rojas R: Differences in exhaled breath condensate $\mathrm{pH}$ measurements between samples obtained with two commercial devices. Respir Med 2007;101:1715-1720.

96 Cruz MJ, Sánchez-Vidaurre S, Romero PV, Morell F, Muñoz X: Impact of age on $\mathrm{pH}$, 8 -isoprostane, and nitrogen oxides in exhaled breath condensate. Chest 2009;135:462-467.

97 Antus B, Barta I, Kullmann T, Lazar Z, Valyon M, Horvath I, Csiszer E: Assessment of exhaled breath condensate $\mathrm{pH}$ in exacerbations of asthma and chronic obstructive pulmonary disease. Am J Respir Crit Care Med 2010;182: 1492-1497.

98 Tomasiak-Lozowska MM, Zietkowski Z, Prz eslaw K, Tomasiak M, Skiepko R, BodzentaLukaszyk A: Inflammatory markers and acidbase equilibrium in exhaled breath condensate of stable and unstable asthma patients. Int Arch Allergy Immunol 2012;159:121129.
Asthma Control and Noninvasive Inflammation Studies
Int Arch Allergy Immunol 2015;166:1-12 DOI: $10.1159 / 000371849$ 
99 Kostikas K, Papatheodorou G, Ganas K, Psathakis K, Panagou P, Loukides S: $\mathrm{pH}$ in expired breath condensate of patients with inflammatory airways diseases. Am J Respir Crit Care Med 2002;165:1364-1370.

100 Muñoz X, Velasco MI, Culebras M, Roca O, Morell F, Cruz MJ: Utility of exhaled breath condensate $\mathrm{pH}$ for diagnosing occupational asthma. Int Arch Allergy Immunol 2012; 159:313-320.

101 Sanchez-Vidaurre S, Cruz MJ, Gomez-Ollés S, Morell F, Muñoz X: Diagnostic utility of exhaled breath condensate analysis in conjunction with specific inhalation challenge in individuals with suspected work-related asthma. Ann Allergy Asthma Immunol 2012;108:151-156.

102 Ciencewicki J, Trivedi S, Kleeberger SR: Oxidants and the pathogenesis of lung diseases. J Allergy Clin Immunol 2008;122:456-468.

103 Loukides S, Bouros D, Papatheodorou G, Panagou P, Siafakas NM: The relationship among hydrogen peroxide in expired breath condensate, airway inflammation, and asthma severity. Chest 2002;212:338-346.

104 Horvath I Donnelly LE, Kiss A, Balint B, Kharitonov SA, Barnes PJ: Exhaled nitric oxide and hydrogen peroxide concentrations in asthmatic smokers. Respiration 2004;7: 463-468.
105 Horvath I, Donnelly LE, Kiss A, Kharitonov SA, Lim S, Chung KF, Barnes PJ: Combined use of exhaled hydrogen peroxide and nitric oxide in monitoring asthma. Am J Respir Crit Care Med 1998;158:1042-1046.

106 Antezak A, Nowak D, Shariati B, Król M, Piasecka G, Kurmanowska Z: Increased hydrogen peroxide and thiobarbituric acid-reactive products in expired breath condensate of asthmatic patients. Eur Respir J 1997; 10:1235-1241.

107 Teng Y, Sun P, Zhang J, Yu R, Bai J, Yao X, Huang M, Adcock IM, Barnes PJ: Hydrogen peroxide in exhaled breath condensate in patients with asthma. Chest 2011;140:108116.

108 Murata K, Fujimoto K, Kitaguchi Y, Horiuchi T, Kubo K, Honda T: Hydrogen peroxide content and $\mathrm{pH}$ of expired breath condensate from patients with asthma and COPD. COPD 2014;11:81-87.

109 Montuschi P, Corradi M, Ciabattoni G, Nightingale J, Khartonov SA, Barnes PJ: Increased 8-isoprostane, a marker of oxidative stress, in exhaled condensate of asthma patients. Am J Respir Crit Care Med 1999;160: 216-220.

110 Piotrowski WJ, Majewski S, Marczak J, Kurmanowska Z, Górski P, Antczak A: Exhaled breath 8 -isoprostane as a marker of asthma severity. Arch Med Sci 2012;8:515-520.
111 Antczak A, Montuschi P, Kharitonov S, Gorski P, Barnes PJ: Increased exhaled cysteinyl-leukotrienes and 8-isoprostane in aspirin-induced asthma. Am J Respir Crit Care Med 2002;166:301-306.

112 Battaglia S, den Hertog H, Timmers MC, Laceroms SP, Vignola AM, Rabe KF, Bellia V, Hiemstra PS, Sterk PJ: Small airways function and molecular markers in exhaled air in mild asthma. Thorax 2005;60:639-644.

113 Kostikas K, Papatheodorou G, Psathakis K, Panagou P, Loukides S: Prostaglandin E2 in the expired breath condensate of patients with asthma. Eur Respir J 2003;22:743-747.

114 Loukides S, Kontogianni K, Hillas G, Horvath $\mathrm{I}$ : Exhaled breath condensate in asthma: from bench to bedside. Curr Med Chem 2011;18:1432-1443.

115 Robroeks CM, van Vliet D, Jobsis O, Braekers R, Rijkers GT, Wodzig WK, Bast A, Zimmermann LJ, Dompeling E: Prediction of asthma exacerbations in children: results of a one-year prospective study. Clin Exp Allergy 2012;42:792-798.

116 Kazani S, Planaguma A, Ono E, Bonini M, Zahid M, Marigowda G, Wechsler ME, Levy $\mathrm{BD}$, Israel $\mathrm{E}$ : Exhaled breath condensate eicosanoid levels associate with asthma and its severity. J Allergy Clin Immunol 2013; 132:547-553. 